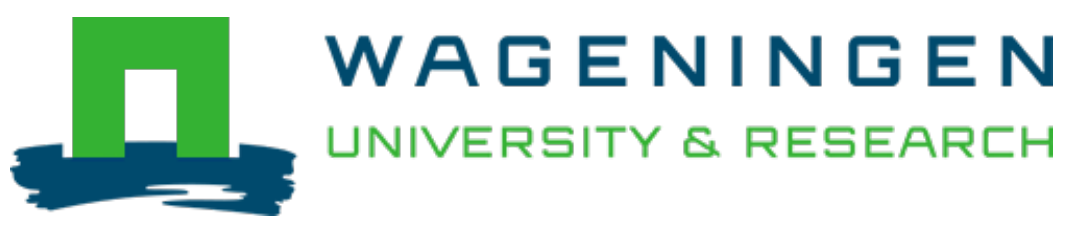

\title{
Effects of carbohydrate addition frequencies on biofloc culture of Pacific white shrimp (Litopenaeus vannamei)
}

\author{
Aquaculture \\ Tinh, Tran Huu; Hai, Tran Ngoc; Verreth, Johan A.J.; Verdegem, Marc C.J. \\ https://doi.org/10.1016/j.aquaculture.2020.736271
}

This article is made publicly available in the institutional repository of Wageningen University and Research, under the terms of article $25 \mathrm{fa}$ of the Dutch Copyright Act, also known as the Amendment Taverne. This has been done with explicit consent by the author.

Article 25 fa states that the author of a short scientific work funded either wholly or partially by Dutch public funds is entitled to make that work publicly available for no consideration following a reasonable period of time after the work was first published, provided that clear reference is made to the source of the first publication of the work.

This publication is distributed under The Association of Universities in the Netherlands (VSNU) 'Article $25 \mathrm{fa}$ implementation' project. In this project research outputs of researchers employed by Dutch Universities that comply with the legal requirements of Article $25 \mathrm{fa}$ of the Dutch Copyright Act are distributed online and free of cost or other barriers in institutional repositories. Research outputs are distributed six months after their first online publication in the original published version and with proper attribution to the source of the original publication.

You are permitted to download and use the publication for personal purposes. All rights remain with the author(s) and / or copyright owner(s) of this work. Any use of the publication or parts of it other than authorised under article $25 \mathrm{fa}$ of the Dutch Copyright act is prohibited. Wageningen University \& Research and the author(s) of this publication shall not be held responsible or liable for any damages resulting from your (re)use of this publication.

For questions regarding the public availability of this article please contact openscience.library@,wur.nl 


\title{
Effects of carbohydrate addition frequencies on biofloc culture of Pacific white shrimp (Litopenaeus vannamei)
}

\author{
Tran Huu Tinh ${ }^{\text {a }}$, Tran Ngoc Hai ${ }^{b}$, Johan A.J. Verreth ${ }^{\text {a }}$, Marc C.J. Verdegem ${ }^{\text {a, }}$ \\ ${ }^{a}$ Aquaculture and Fisheries Group, Wageningen University, the Netherlands \\ ${ }^{\mathrm{b}}$ College of Aquaculture and Fisheries, Can Tho University, Viet Nam
}

\section{A R T I C L E I N F O}

\section{Keywords:}

Biofloc technology

Carbohydrate addition frequency

Litopenaeus vannamei

Nutrient retention

\begin{abstract}
A B S T R A C T
In Pacific white shrimp culture, adding organic carbohydrate to the pond besides feed improves water quality and shrimp performance. While the feeding frequency has significant effects on shrimp production, how often carbohydrate should be added remains unknown. This research investigated the effects of carbohydrate addition frequency of 1,3 , and 6 times per day on Pacific white shrimp production. Tapioca powder was used as carbohydrate source to maintain an input C:N ratio of 12 . The same daily ration of tapioca was applied, but divided into equal portions according to the application frequency. The shrimp performance was better in carbohydrateadded systems than in a conventional system without additional carbohydrate, but the carbon retention efficiency was lower. Splitting daily dosage of carbohydrate into more frequent additions had no significant effect on Pacific white shrimp performance, and carbon and nitrogen retentions. A carbohydrate addition frequency of once per day is recommended for good performance of Pacific white shrimp in biofloc rearing systems.
\end{abstract}

\section{Introduction}

During the last decade, biofloc technology (BFT) emerged as a potential solution for improving the sustainability of aquaculture (Bossier and Ekasari, 2017). In this technology, carbon is added through organic carbohydrate additions, to provide energy for the assimilation of nitrogenous compounds into microbial biomass (Avnimelech, 2009). This reduces the levels of ammonia, the need for water exchange, and increases the concentration of flocculated materials (biofloc) which can serve as natural food for the cultured animals (Crab et al., 2012).

The application of biofloc technology has been tested in an extensive range of culture species, including Pacific white shrimp, Litopenaeus vannamei. This species stood at number one in value and number six in production, accounting for nearly $4 \%$ (or 4.45 million tons) of world aquaculture production in 2017 (Junning et al., 2019), and continued growing reaching 4.97 million tons in 2018 (FAO, 2020). Cultured Pacific white shrimp are often fed multiple times per day or continuously in intensive systems. The majority of research recommended a feeding frequency of 3-4 times daily, mostly during day time, to ensure good growth (de Lima et al., 2009; Peixoto et al., 2018; Pontes et al., 2008; Robertson et al., 1993; Wasielesky Jr. et al., 2020). This spaced feeding stimulates foraging and ingestion activities (de Lima et al., 2009; Pontes et al., 2008), and enzyme production (Peixoto et al., 2018) in Pacific white shrimp. Higher feeding frequencies may not be advantageous for growth and survival while being less cost-effective (Carvalho and Nunes, 2006; Velasco et al., 1999). Recent research, however, recommends ondemand feeding system for improved shrimp growth (Reis et al., 2020).

In biofloc technology research, the organic carbon source is often added to the system once daily, regardless of feeding frequencies (Panigrahi et al., 2019; Xu and Pan, 2012; Xu et al., 2016). By splitting daily dosage of $\mathrm{CHO}$ into more frequent applications per day, less organic carbon enters the biofloc system each time, which may help reduce the fluctuation of oxygen. As this organic carbon is primarily consumed by heterotrophic bacteria, frequent $\mathrm{CHO}$ addition increases the availability of food over a longer time period. This may boost the growth of heterotrophic bacteria, which have a lower alkalinity requirement compared to autotrophic bacteria (Ebeling et al., 2006), and help to reduce fluctuations in $\mathrm{pH}$ and alkalinity. A stable culture environment promotes growth and survival of the cultured animals (Janeo et al., 2009). However, more frequent addition of CHO will also increase labor cost, and therefore may reduce the adoption of the technology. Lower $\mathrm{CHO}$ addition frequencies when proven to be more beneficial to shrimp culture system would allow the simplification and facilitate the dissemination and adoption of the biofloc technology.

\footnotetext{
* Corresponding author at: Zodiac building, De Elst 1, 6708 WD, Wageningen, the Netherlands.

E-mail address: marc.verdegem@wur.nl (M.C.J. Verdegem).
} 
Therefore, this research aimed at comparing the effects of different $\mathrm{CHO}$ addition frequencies on Pacific white shrimp production, water quality, biofloc and periphyton in a mixed photoautotrophic-heterotrophic biofloc system with minimum water exchange.

\section{Materials and methods}

\subsection{Experimental design}

This experiment was done at the aquatic experimental facilities in College of Aquaculture and Fisheries, Can Tho University, Vietnam. The experiment consisted of 3 treatments of carbohydrate (CHO) addition frequency in triplicate, including one addition per day after mid-day feeding ( $\mathrm{CHO} 1$ ), three additions per day after every feeding ( $\mathrm{CHO} 3$ ), and six additions per day before and after every feeding ( $\mathrm{CHO}$ 6). Another treatment where no $\mathrm{CHO}$ was added ( $\mathrm{CHO} 0$ ) was included to demonstrate the effect of $\mathrm{CHO}$ addition as Xu et al. (2016) showed that system without $\mathrm{CHO}$ addition performed equally well. The shrimp were fed three times daily at $08.00,12.00$, and 16.00 . The experiment lasted for 6 weeks from August to September 2018.

\subsection{Experimental site preparation}

The experiment was conducted outdoor. The experimental site was covered with a transparent plastic film to prevent the effects of rain water intrusion, while providing the ambient lighting to experimental tanks. Twelve plastic tanks $\left(0.5 \mathrm{~m}^{3}\right.$ total volume) were cleaned prior to the addition of saline water, and employed for the experiment.

Sea water (80 ppt salinity) was diluted to $15 \mathrm{ppt}$ salinity, and alkalinity was adjusted to $140 \mathrm{mg} / \mathrm{L}$ by adding sodium bicarbonate. Three hundred liters of disinfected and filtered water were pumped into each experimental tank. All tanks were continuously aerated to maintain the dissolved oxygen level above $6 \mathrm{mg} / \mathrm{L}$.

\subsection{Experimental animals}

As base population, two thousand Pacific white shrimp post-larvae of day 15 were obtained from a nearby hatchery, and nursed in a $2-\mathrm{m}^{3}$ tank at $15 \mathrm{ppt}$ salinity for one month. During this period, shrimp were fed to satiation three times per day with a $48 \%$ protein feed. Rice flour was added to the nursing tank after every feeding to maintain an input C:N ratio of 12 . The amount of rice flour needed was calculated using the following formula, assuming the $48 \%$ protein feed contained $50 \%$ carbon $\left(\%\right.$ Carbon $\left._{\text {feed }}\right)$ and $7.7 \%$ nitrogen $\left(\%\right.$ Nitrogen $\left._{\text {feed }}\right)$, and rice flour contained $80 \%$ carbon $\left(\%\right.$ Cabon $\left._{\mathrm{CHO}}\right)$ and $0.5 \%$ nitrogen $\left(\%\right.$ Nitrogen $\left._{\mathrm{CHO}}\right)$ :

$C: N$ ratio

$$
=\frac{\left(\text { Weight }_{\text {feed }} \times \% \text { Carbon }_{\text {feed }}\right)+\left(\text { Weight }_{\text {CHO }} \times \% \text { Carbon }_{\text {CHO }}\right)}{\left(\text { Weight }_{\text {feed }} \times \% \text { Nitrogen }_{\text {feed }}\right)+\left(\text { Weight }_{C H O} \times \% \text { Nitrogen }_{C H O}\right)} \times 100
$$

As part of the nitrogen in feed was retained by the shrimp, the actual input C:N ratio entering the system would be higher. After one month of nursing, groups of 36 shrimp of similar size $(0.61 \pm 0.02 \mathrm{~g}$ average individual weight) were randomly taken from the base population, weighed for initial total biomass and stocked into each experimental tank, concurring to a stocking density of $120 \mathrm{ind} / \mathrm{m}^{3}$. Shrimp were fed three times daily at $08.00,12.00$, and 16.00 with a commercial feed of $43 \%$ protein (Skretting, Vietnam) during the experiment. A feeding table was made assuming a feed conversion ratio (FCR) of 1 , a feeding rate of $5.5 \%$ shrimp body weight (BW), and a mortality rate of $5 \%$ over 6 -week culture period. Tapioca powder was used as the $\mathrm{CHO}$ source during the experimental period. Lab analysis prior to the experiment showed that the $43 \%$ protein feed contained $33 \%$ carbon and $6.9 \%$ nitrogen, and tapioca powder contained $66 \%$ carbon and $0.5 \%$ nitrogen. To maintain an input C:N ratio of 12 , the amount of tapioca powder needed was $846 \mathrm{~g}$ per kilogram of feed, calculated using formula (1).

\subsection{Sampling and sample analysis}

During the experiment, total ammonia nitrogen (TAN), nitrite nitrogen $\left(\mathrm{NO}_{2}-\mathrm{N}\right)$, and nitrate nitrogen $\left(\mathrm{NO}_{3}-\mathrm{N}\right)$ were monitored daily with test kits (Sera $\mathrm{GmbH}$, Germany). Water samples were collected on a weekly basis from each tank. The sampling took place $30 \mathrm{~min}$ after the first feeding of the day. All samples were stored at $4{ }^{\circ} \mathrm{C}$ if immediate analysis was not possible. Water samples were analyzed for total suspended solids (TSS), volatile suspended solids (VSS), chlorophyll $a$ (Chla), total nitrogen (TN), TAN, $\mathrm{NO}_{2}-\mathrm{N}, \mathrm{NO}_{3}-\mathrm{N}$ (APHA, 1995), and total carbon (TC) (QuickTOCultra, LAR Process Analysers AG, Germany).

The number and weight of shrimp were determined only at stocking and harvest to minimize handling stress. Shrimp samples were collected at the beginning and end of the experiment. Biofloc and periphyton samples were collected at the end of the experiment. Shrimp, biofloc, and periphyton samples were immediately sent to Mekonglab Testing Center (NhoNho Technology Ltd. Co., Vietnam) after their collection for the proximate analysis of crude protein (ISO 5983, 2005), crude fat (ISO 6492, 1999), ash (ISO 5984, 2002), and total carbon (QuickTOCultra, LAR Process Analysers AG, Germany).

\subsection{Data analysis}

Shrimp specific growth rate (SGR) was calculated as follow:

$S G R\left(\% \frac{B W}{d a y}\right)=\frac{\ln (\text { final BW })-\ln (\text { initial BW })}{\text { Days of culture }} \times 100$

The nitrogen content of shrimp, biofloc, and periphyton were approximated to be $16 \%$ of crude protein by weight. Carbon and nitrogen retention efficiencies in the shrimp, water, biofloc, and overall system were calculated by dividing the difference between the starting (in water and stocked shrimp) and the harvested (in water, biofloc, and harvested shrimp) amounts by the total amount of input from feed and $\mathrm{CHO}$, as simplified in the equation below:

Retention efficiency $(\%)=\frac{\text { Total at harvest }(\mathrm{g})-\text { Total at start }(\mathrm{g})}{\text { Total input }(\mathrm{g})} \times 100$

Statistical analysis was performed with IBM SPSS Statistics 25 software (IBM Corporation, NY, USA). The effects of treatment on Pacific white shrimp production parameters, proximate compositions of shrimp, biofloc and periphyton, and nutrient retention efficiency were compared using One-way ANOVA. The effects of treatment on water quality parameters were analyzed with Repeated measure ANOVA. The probability value ( $P$ value) of less than 0.05 was used to indicate significant differences. Least significant difference (LSD) post-hoc test was performed when a significant effect was found.

\section{Results}

\subsection{Effects on Pacific white shrimp production parameters}

Shrimp production parameters are summarized in Table 1 . The harvested biomass, survival rate, and FCR were not different among treatments $(P>0.05)$. The shrimp specific growth rate was not different among treatments, but tended to be higher shrimp where additional $\mathrm{CHO}$ was added $(P<0.1)$. Besides, the $\mathrm{CHO}$ addition resulted in higher FCR-CHO (FCR in which carbohydrate was considered as feed in the calculation) $(P<0.05)$. Shrimp final body weight was significantly improved by the $\mathrm{CHO}$ addition, but was similar among different addition frequencies $(\mathrm{P}<0.05)$.

The proximate composition of harvested shrimp was similar among all treatments $(\mathrm{P}>0.05)$, ranging in dry weight (DW) between 77.6 and $78.4 \%$ for crude protein, $5.0-5.2 \%$ for crude fat and $13.4-14.3 \%$ for ash (Table 2). Shrimp contained a similar carbon to nitrogen ratio among 
Table 1

Pacific white shrimp production parameters in the six-week experiment.

\begin{tabular}{|c|c|c|c|c|c|c|}
\hline Treatments & $\begin{array}{l}\text { Final } \\
\text { BW }\end{array}$ & $\begin{array}{l}\text { Harvested } \\
\text { biomass }\end{array}$ & $\begin{array}{l}\text { Survival } \\
\text { rate }\end{array}$ & FCR & $\begin{array}{l}\text { FCR- } \\
\text { CHO }\end{array}$ & SGR \\
\hline (CHO/day) & $\begin{array}{l}\text { (g/ } \\
\text { ind) }\end{array}$ & (g) & (\%) & & & $\begin{array}{l}\text { (\% } \\
\text { BW/ } \\
\text { day) }\end{array}$ \\
\hline CHO 0 & $\begin{array}{l}7.2 \pm \\
0.6^{\mathrm{a}}\end{array}$ & $241 \pm 18$ & $93 \pm 4$ & $\begin{array}{l}0.98 \\
\pm 0.08\end{array}$ & $\begin{array}{l}0.98 \pm \\
0.08^{\mathrm{a}}\end{array}$ & $\begin{array}{l}5.9 \pm \\
0.2\end{array}$ \\
\hline CHO 1 & $\begin{array}{l}8.3 \pm \\
0.3^{\mathrm{b}}\end{array}$ & $266 \pm 22$ & $89 \pm 10$ & $\begin{array}{l}0.87 \\
\pm 0.08\end{array}$ & $\begin{array}{l}1.62 \pm \\
0.15^{\mathrm{b}}\end{array}$ & $\begin{array}{l}6.2 \pm \\
0.1\end{array}$ \\
\hline CHO 3 & $\begin{array}{l}8.1 \pm \\
0.2^{\mathrm{b}}\end{array}$ & $223 \pm 61$ & $88 \pm 2$ & $\begin{array}{l}1.14 \\
\pm 0.42\end{array}$ & $\begin{array}{l}2.11 \pm \\
0.77^{\mathrm{b}}\end{array}$ & $\begin{array}{l}6.2 \pm \\
0.1\end{array}$ \\
\hline CHO 6 & $\begin{array}{l}8.0 \pm \\
0.2^{\mathrm{b}}\end{array}$ & $250 \pm 30$ & $86 \pm 8$ & $\begin{array}{l}0.94 \\
\pm 0.12\end{array}$ & $\begin{array}{l}1.74 \pm \\
0.22^{\mathrm{b}}\end{array}$ & $\begin{array}{l}6.2 \pm \\
0.1\end{array}$ \\
\hline$P$ values & 0.039 & 0.547 & 0.712 & 0.522 & 0.001 & 0.053 \\
\hline
\end{tabular}

Values are means ( \pm SD) of three replicate tanks per treatment (CHO addition times/day). BW = body weight, FCR $=$ feed conversion ratio, FCR-CHO $=$ feed conversion ratio accounting $\mathrm{CHO}$ as feed, $\mathrm{SGR}=$ specific growth rate. Probability $(P)$ values in bold indicate significant effects $(P<0.05)$. Different superscripts indicate significant differences among treatment means by column.

Table 2

Proximate composition of shrimp at the end of the six-week experiment.

\begin{tabular}{llllll}
\hline Treatments & DW & $\begin{array}{l}\text { Crude } \\
\text { protein }\end{array}$ & Crude fat & Ash & C:N ratio \\
& & $(\% \mathrm{DW})$ & $(\% \mathrm{DW})$ & $(\% \mathrm{DW})$ & \\
\hline (CHO/day) & $(\%)$ & $78.9 \pm 1.1$ & $5.0 \pm 0.3$ & $14.3 \pm 1.2$ & $3.7 \pm 0.2$ \\
CHO 0 & $21.6 \pm 0.5$ & $7.3 \pm 1.6$ & $5.2 \pm 1.3$ & $14.1 \pm 0.9$ & $4.4 \pm 0.8$ \\
CHO 1 & $22.0 \pm 0.9$ & $77.3 \pm 0.4$ & $3.4 \pm 0.3$ \\
CHO 3 & $21.8 \pm 0.4$ & $79.7 \pm 1.4$ & $5.2 \pm 1.4$ & $14.1 \pm 0.9$ & $3.4 \pm 0.3$ \\
CHO 6 & $22.4 \pm 0.9$ & $79.7 \pm 1.9$ & $5.2 \pm 0.6$ & $13.9 \pm 0.5$ & 3.4 \\
$P$ values & 0.947 & 0.531 & 0.179 & 0.985 & 0.071 \\
\hline
\end{tabular}

Values are means $( \pm$ SD) of three replicate tanks per each treatment. DW $=$ dry weight.

treatments $(\mathrm{P}>0.05)$.

\subsection{Effects on water quality}

During the experiment, environmental parameters fluctuated in the ranges of 5.9-6.8 mg/L for oxygen, 7.9-8.5 for $\mathrm{pH}$, and $27-30{ }^{\circ} \mathrm{C}$ for temperature. Repeated measure ANOVA showed that all measured water quality parameters, except organic nitrogen (ON), changed significantly over the weeks $\left(\mathrm{P}_{\text {Time }}<0.05\right)$ (Table 3$)$. The effects of treatment on TSS, TAN, TN and ON were not significant $\left(\mathrm{P}_{\text {Treatment }}>\right.$ 0.05). Chlorophyll a concentration was significantly higher in the $\mathrm{CHO}$ 0 treatment, while VSS and TC concentrations were significantly higher in treatments where $\mathrm{CHO}$ was added $\left(\mathrm{P}_{\text {Treatment }}<0.05\right)$. The treatments showed different effects on inorganic nitrogen (IN) and $\mathrm{NO}_{3}-\mathrm{N}$ in water at different moments in time during the experiment $\left(\mathrm{P}_{\text {Treatment }} \mathrm{x}\right.$ Time $<$
0.05).

The VSS concentrations increased over the weeks in all treatments, reaching the highest level of $198 \mathrm{mg} / \mathrm{L}$ at the end of the experiment (Fig. 1). Increasing the $\mathrm{CHO}$ application frequency from 1 to 6 times per day showed no effect on the VSS. The TSS concentrations (Figure not shown) showed a similar pattern, and had a correlation coefficient of 0.93 with VSS. The chlorophyll $a$ concentration showed more fluctuations, ranging between 110 and $337 \mu \mathrm{g} / \mathrm{L}$ (Fig. 2). The chlorophyll $a$ concentration increased more rapidly in the $\mathrm{CHO} 0$ treatment, reaching the highest level of $337 \mu \mathrm{g} / \mathrm{L}$ after one week and remaining relatively constant until the end of the trial. Meanwhile, different $\mathrm{CHO}$ addition frequencies showed similar effect on Chla concentration.

\subsection{Biofloc and periphyton proximate compositions}

Biofloc and periphyton proximate compositions are shown in Table 4 and Table 5, respectively. One-way ANOVA showed that biofloc protein and fat contents, and C:N ratio were not different among treatments. Biofloc ash content was significantly higher in the $\mathrm{CHO} 0$ treatment than in treatments where $\mathrm{CHO}$ was added once or thrice per day $(P<0.05)$, but was similar to that in treatment where $\mathrm{CHO}$ was added six times per day $(P>0.05)$. Regarding periphyton proximate composition, no significant difference was identified among treatments $(P>0.05)$.

\subsection{Nutrient retention efficiency}

Carbon retention in terms of percentage of input and absolute amount is shown in Fig. 3. One-way ANOVA showed that the CHO 0 treatment had significantly higher carbon retention (\% input) in shrimp, biofloc, and water and significantly lower carbon loss (unaccounted carbon in periphyton and through evaporation) compared to other treatments $(P>0.05)$. Different $\mathrm{CHO}$ addition frequencies showed similar effect on carbon retention efficiency. In term of absolute amount, adding $\mathrm{CHO}$ once per day resulted in higher carbon retention in shrimp, and lower carbon loss compared to adding 3 or 6 times daily. Nitrogen retention in terms of percentage of input and absolute amount (Fig. 4) was similar among all treatments $(\mathrm{P}>0.05)$.

\section{Discussion}

The average final shrimp biomass by treatment was $14 \%$ better than predicted according to the feeding table provided by the feed company, in spite of the $5 \%$ higher than anticipated mortality. The slightly higher mortality increased the amount of feed per shrimp explaining partially the $21 \%$ increase in average individual body weight by treatment reached at the end of the experiment (Liu et al., 2017; Sookying et al., 2011). Carbohydrate addition significantly increased the individual final shrimp body weight $(P<0.05)$ and numerically improved the SGR $(P<0.1)$. No differences were observed in survival and FCR with $\mathrm{CHO}$

Table 3

Summary of water quality parameters in the six-week experiment.

\begin{tabular}{|c|c|c|c|c|c|c|c|}
\hline \multirow[t]{2}{*}{ Parameters } & \multicolumn{4}{|c|}{ Treatments (CHO/day) } & \multicolumn{3}{|l|}{$P$ values } \\
\hline & CHO 0 & CHO 1 & CHO 3 & CHO 6 & Treatment & Time & Treatment $\mathrm{x}$ Time \\
\hline TSS (mg/L) & $142 \pm 70$ & $152 \pm 78$ & $160 \pm 71$ & $174 \pm 88$ & 0.145 & 0.000 & 0.424 \\
\hline VSS (mg/L) & $82 \pm 35^{\mathrm{a}}$ & $103 \pm 50^{\mathrm{b}}$ & $105 \pm 42^{\mathrm{b}}$ & $100 \pm 45^{b}$ & 0.003 & 0.000 & 0.127 \\
\hline Chla $(\mu \mathrm{g} / \mathrm{L})$ & $295 \pm 30^{a}$ & $216 \pm 71^{\mathrm{ab}}$ & $203 \pm 53^{b}$ & $187 \pm 47^{\mathrm{b}}$ & 0.023 & 0.000 & 0.203 \\
\hline TAN (mg/L) & $1.4 \pm 1$ & $1.9 \pm 1.8$ & $1.7 \pm 1.5$ & $1.9 \pm 1.6$ & 0.566 & 0.002 & 0.389 \\
\hline $\mathrm{NO}_{2}-\mathrm{N}(\mathrm{mg} / \mathrm{L})$ & $1.6 \pm 2^{\mathrm{a}}$ & $0.7 \pm 1.6^{\mathrm{b}}$ & $1.3 \pm 2.8^{\mathrm{ab}}$ & $1.2 \pm 2.8^{\mathrm{ab}}$ & 0.042 & 0.000 & 0.122 \\
\hline $\mathrm{NO}_{3}-\mathrm{N}(\mathrm{mg} / \mathrm{L})$ & $2.2 \pm 2.8^{\mathrm{a}}$ & $0.9 \pm 0.4^{\mathrm{b}}$ & $1.1 \pm 0.7^{\mathrm{b}}$ & $1.4 \pm 1.1^{\mathrm{b}}$ & 0.001 & 0.000 & 0.000 \\
\hline $\mathrm{TN}(\mathrm{mg} / \mathrm{L})$ & $7.6 \pm 1.3$ & $8.1 \pm 1.5$ & $8.6 \pm 2.7$ & $8.6 \pm 1.3$ & 0.607 & 0.013 & 0.585 \\
\hline IN (mg/L) & $5.2 \pm 5.7^{\mathrm{a}}$ & $3.6 \pm 3.4^{\mathrm{b}}$ & $4.1 \pm 4^{\mathrm{ab}}$ & $4.5 \pm 4.5^{\mathrm{ab}}$ & 0.036 & 0.000 & 0.023 \\
\hline $\mathrm{ON}(\mathrm{mg} / \mathrm{L})$ & $4.9 \pm 1.4$ & $5.4 \pm 0.8$ & $6.1 \pm 1.4$ & $5.6 \pm 1.2$ & 0.676 & 0.381 & 0.410 \\
\hline $\mathrm{TC}(\mathrm{mg} / \mathrm{L})$ & $38 \pm 4^{\mathrm{a}}$ & $43 \pm 5^{b}$ & $42 \pm 4.9^{b}$ & $42 \pm 5.1^{\mathrm{ab}}$ & 0.014 & 0.000 & 0.100 \\
\hline
\end{tabular}

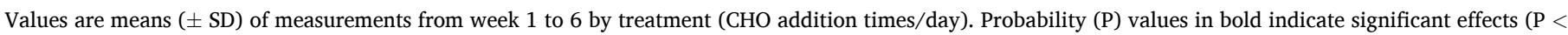
0.05). Different superscripts indicate significant differences among treatment means on one row. 


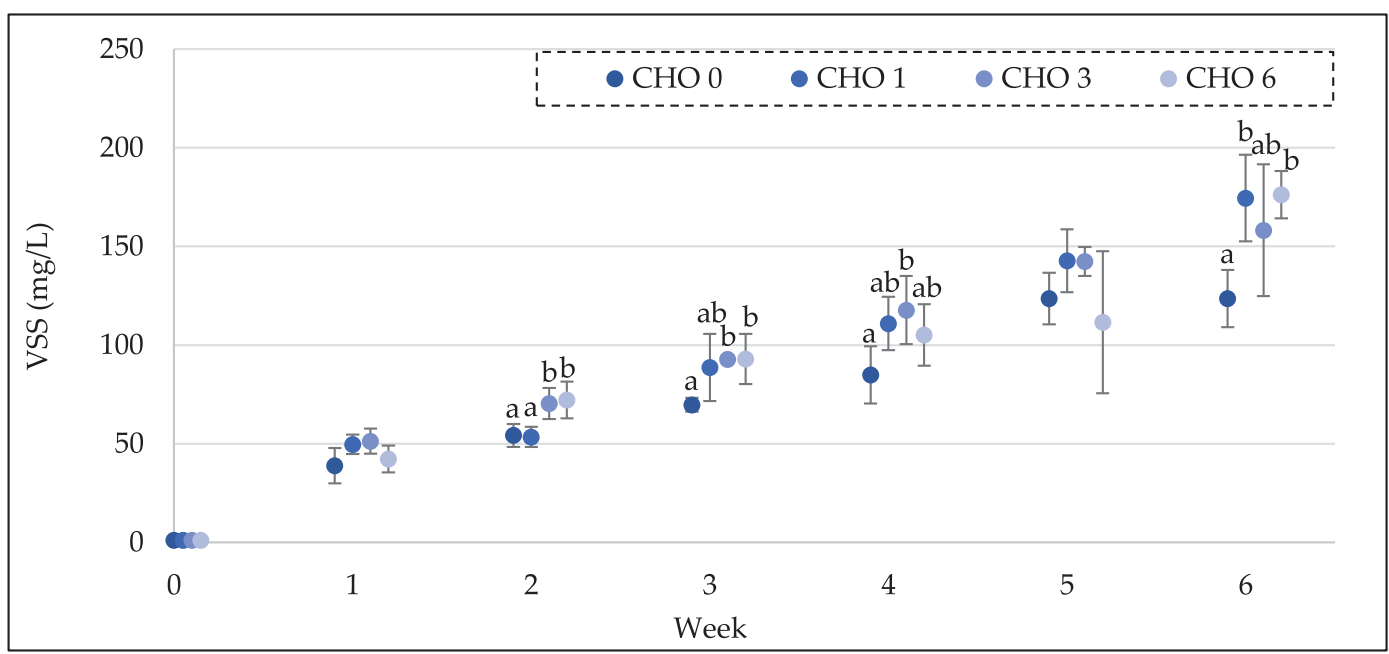

Fig. 1. Weekly changes of volatile suspended solids (VSS) by treatment (CHO addition times/day). Values are means ( \pm SD) of three replicate tanks per treatment. Samples from different treatment tanks were taken on the same day weekly. Data points in each sampling day were presented one beside the other to increase visibility to avoid overlapping of error bars in the graph. For each week, different letters above data points indicate significant differences.

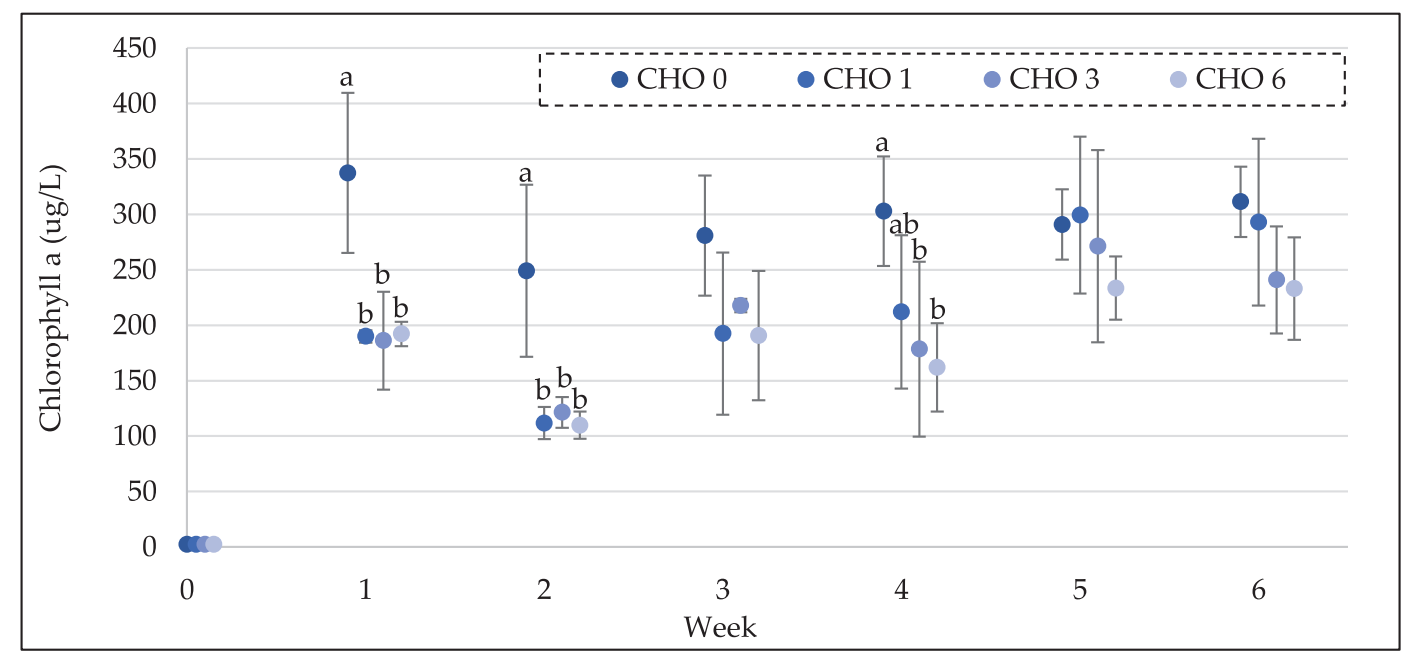

Fig. 2. Weekly changes of chlorophyll $a$ concentration in water by treatment (CHO addition times/day). Values are means ( \pm SD) of three replicate tanks per treatment. Samples from different treatment tanks were taken on the same day weekly. Data points in each sampling day were presented one beside the other to increase visibility to avoid overlapping of error bars in the graph. For each week, different letters above data points indicate significant differences.

Table 4

Biofloc proximate composition at the end of the six-week experiment.

\begin{tabular}{|c|c|c|c|c|c|}
\hline Treatments & Moisture & $\begin{array}{l}\text { Crude } \\
\text { protein }\end{array}$ & $\begin{array}{l}\text { Crude } \\
\text { fat }\end{array}$ & Ash & $\mathrm{C}: \mathrm{N}$ ratio \\
\hline (CHO/day) & (\%) & (\% DW) & $(\% \mathrm{DW})$ & $(\% \mathrm{DW})$ & \\
\hline $\mathrm{CHO} O$ & $92.2 \pm 0.9$ & $29.7 \pm 0.9$ & $\begin{array}{l}2.8 \pm \\
0.8\end{array}$ & $45.3 \pm 2.0^{\mathrm{a}}$ & $\begin{array}{l}3.24 \pm \\
0.42\end{array}$ \\
\hline CHO 1 & $92.7 \pm 1.2$ & $29.0 \pm 3.6$ & $\begin{array}{l}3.5 \pm \\
0.9\end{array}$ & $\begin{array}{l}37.3 \pm \\
3.2^{\mathrm{b}}\end{array}$ & $\begin{array}{l}3.77 \pm \\
1.02\end{array}$ \\
\hline CHO 3 & $91.7 \pm 1.1$ & $27.6 \pm 2.2$ & $\begin{array}{l}2.5 \pm \\
0.8\end{array}$ & $\begin{array}{l}36.3 \pm \\
3.8^{\mathrm{b}}\end{array}$ & $\begin{array}{l}3.56 \pm \\
0.12\end{array}$ \\
\hline CHO 6 & $93.0 \pm 0.3$ & $28.1 \pm 2.2$ & $\begin{array}{l}2.7 \pm \\
0.2\end{array}$ & $\begin{array}{l}39.5 \pm \\
0.9^{\mathrm{ab}}\end{array}$ & $\begin{array}{l}3.75 \pm \\
0.86\end{array}$ \\
\hline P values & 0.433 & 0.705 & 0.453 & 0.014 & 0.781 \\
\hline
\end{tabular}

Values are means $( \pm$ SD) of three replicate tanks per treatment (CHO addition times/day). Probability ( $P$ ) value in bold indicates significant effect $(\mathrm{P}<0.05)$. Different superscripts indicate significant differences among means in a column.

addition, in contrast to Gao et al. (2012) and Panigrahi et al. (2019) who observed improved survival and FCR when administrating CHO. While
Table 5

Periphyton proximate composition at the end of the six-week experiment.

\begin{tabular}{|c|c|c|c|c|c|}
\hline Treatments & Moisture & $\begin{array}{l}\text { Crude } \\
\text { protein }\end{array}$ & $\begin{array}{l}\text { Crude } \\
\text { fat }\end{array}$ & Ash & C:N ratio \\
\hline (CHO/day) & (\%) & $(\% \mathrm{DW})$ & (\% DW) & (\% DW) & \\
\hline CHO 0 & $88.4 \pm 1.9$ & $51.7 \pm 3.7$ & $6.7 \pm 1.0$ & $\begin{array}{l}40.1 \pm \\
4.5\end{array}$ & $\begin{array}{l}2.49 \pm \\
0.61\end{array}$ \\
\hline CHO 1 & $90.5 \pm 0.4$ & $52.7 \pm 4.9$ & $6.3 \pm 2.1$ & $\begin{array}{l}42.6 \pm \\
4.0\end{array}$ & $\begin{array}{l}2.66 \pm \\
0.62\end{array}$ \\
\hline CHO 3 & $90.2 \pm 0.9$ & $56.2 \pm 8.4$ & $5.5 \pm 0.8$ & $\begin{array}{l}40.9 \pm \\
1.9\end{array}$ & $\begin{array}{l}2.42 \pm \\
0.71\end{array}$ \\
\hline CHO 6 & $90.3 \pm 1.1$ & $57.9 \pm 7.4$ & $7.1 \pm 0.3$ & $\begin{array}{l}41.8 \pm \\
0.9\end{array}$ & $\begin{array}{l}2.45 \pm \\
0.42\end{array}$ \\
\hline$P$ values & 0.194 & 0.625 & 0.485 & 0.784 & 0.959 \\
\hline
\end{tabular}

Values are means $( \pm \mathrm{SD})$ of three replicate tanks per treatment (CHO addition times/day).

the total ammonia nitrogen was similar among treatments, significantly lower nitrite and nitrate nitrogen concentrations where $\mathrm{CHO}$ was added, especially at the frequency of once per day, indicated a more active 


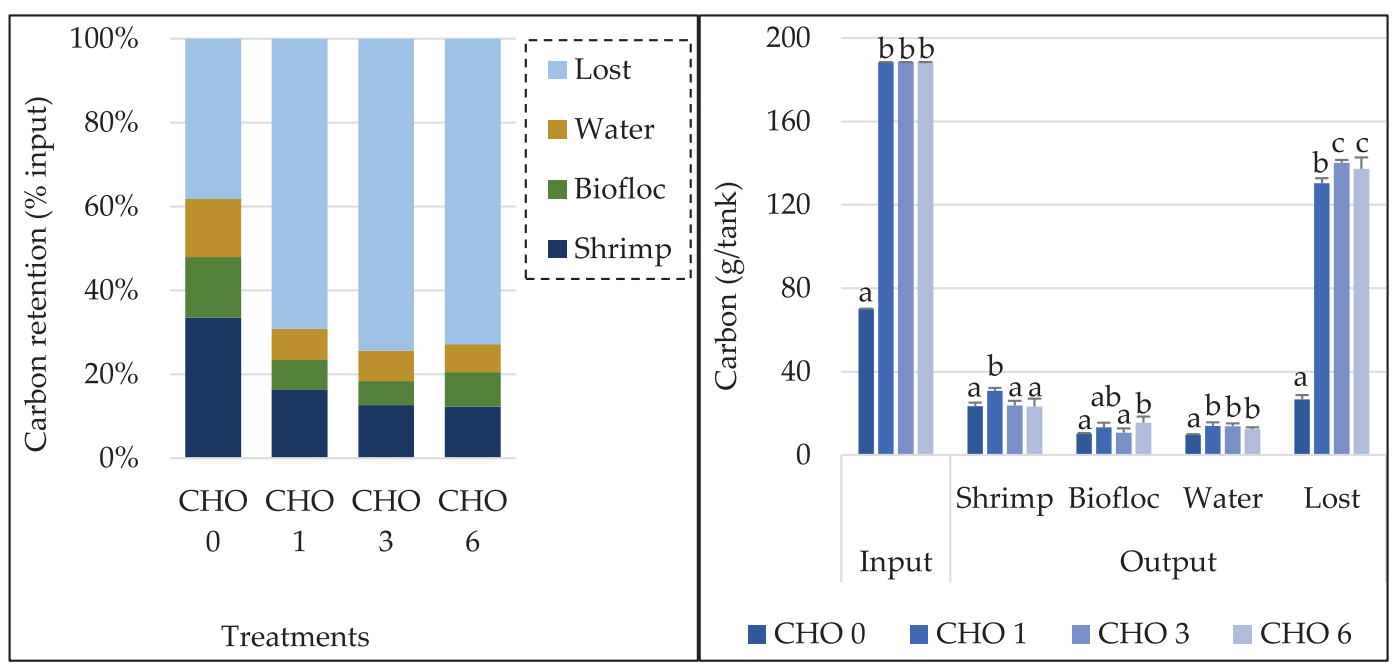

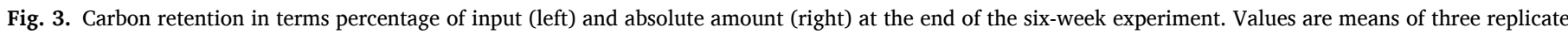
tanks per treatment (CHO addition times/day). Columns in a group with different superscripts are statistically different.
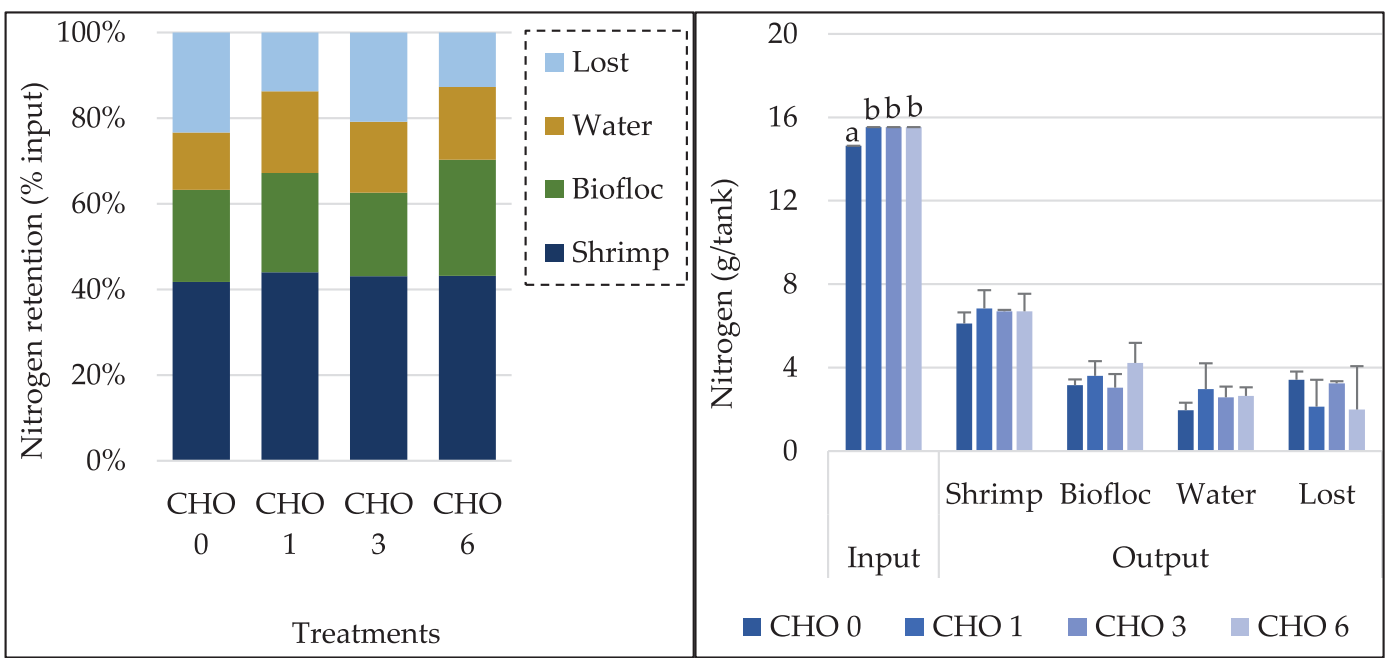

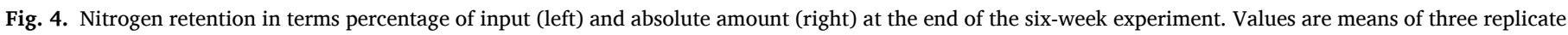
tanks per treatment ( $\mathrm{CHO}$ addition times/day). Columns in a group with different superscripts are statistically different.

bacterial community in these treatments. Besides, significantly higher VSS found in CHO-added treatments suggested a more abundance bacterial content in biofloc compared to biofloc in the $\mathrm{CHO} 0$ treatment.

The addition of carbohydrate prevented the nitrite production, improving the water quality in this research. To test the effects of splitting daily $\mathrm{CHO}$ ration, we maintained a C:N ratio of 12 as higher ratios (e.g. 15 or 18) adversely affected shrimp growth and yield (Xu et al., 2016). Panigrahi et al. (2019), however, suggested an optimal C:N ratio of 15 for improved shrimp growth, water quality, and immunity to bacteria, while Xu and Pan (2012) demonstrated that both C:N ratios of 15 and 20 resulted in similar shrimp growth performance. Emerenciano et al. (2017) suggested an optimal C:N ratio should not be fixed, but rather adjusted during the culture period to maintain good water quality and to meet the nutritional needs of fish or shrimp and biofloc. Therefore, much effort is still needed in creating a standard protocol for biofloc technology that can be widely applied.

Most research on biofloc technology used the CHO addition frequency of once per day, but differed in the time of administration, for example at morning feeding at 6 AM (Gao et al., 2012), after morning feeding at 9 AM (Panigrahi et al., 2019), at mid-day at 12 PM (Xu et al., 2016), or at afternoon feeding at 14 PM (Xu and Pan, 2012). The current research, to our knowledge, was the first to describe the effect of $\mathrm{CHO}$ addition frequency in a biofloc system. In shrimp ponds where dissolved organic carbon is low, microalgae dominate (Xu et al., 2016). Meanwhile, autotrophic bacteria thrive when there is a lot of ammonia and little organic carbon. In biofloc systems with $\mathrm{CHO}$ addition, heterotrophic bacteria become dominant over autotrophic bacteria due to their faster growth rate and more efficient nutrient use (Hargreaves, 2006). However, splitting daily dosage of $\mathrm{CHO}$ to 1 to 3 or 6 addition times per day, which may ensure the continuity of energy source for bacteria growth showed no beneficial effect on shrimp performance, and biofloc growth. Therefore, a CHO addition frequency of once per day is advisable for good shrimp performance and economic labor cost.

As expected, VSS increased over the experimental period, as also reported by Xu et al. (2016). The addition of CHO slowed down the algal growth in the first two weeks, but its effects reduced towards the end of the experiment as the chlorophyll $a$ concentration became similarly high among treatments (Fig. 2). This suggests that the used C:N ratio of 12 was low to maintain the dominance of bacteria over algae. Besides, the sharp increase of chlorophyll $a$ in week 1 (Fig. 2) indicated that the environmental conditions (i.e light intensity, low organic carbon at the start) in this experiment were favorable for algal growth and may have 
facilitated algae in the algae-bacteria interaction in CHO-added treatments. By aiming for an intermediate C:N ratio of 12 (Xu et al., 2016), and spreading the application of $\mathrm{CHO}$ in time, we aimed to maintain a more stable water quality, while keeping algae production going. The results showed that increasing the number of daily $\mathrm{CHO}$ applications has minor effects on system performance. However, it should be noted that these results were for a semi-intensive biofloc system. In intensive and super-intensive biofloc systems, the feed and CHO loads are often near the carrying capacity, and therefore, changing the frequency of adding CHO may have significant effects.

In the present study, the biofloc proximate composition was not different among treatments with and without $\mathrm{CHO}$ addition. This finding contrasted most previous research where biofloc nutritional values increased when CHO was added (Khanjani et al., 2016; Rajkumar et al., 2016; Xu and Pan, 2012, 2014). The contribution of biofloc to the daily nitrogen retention in shrimp may range between 18 and $29 \%$ in high density culture, and tended to increase with the biofloc concentration (Burford et al., 2004). In semi-intensive culture, natural biota may occupy $91 \%$ of stomach contents of the shrimp (Gamboa-delgado et al., 2003). Both biofloc and periphyton presented nutritious food sources for the cultured animal (Bossier and Ekasari, 2017; Wasielesky et al., 2006). While the biofloc protein content in our research was comparable to those in previous research (Khanjani et al., 2016; Kumar et al., 2018; Xu and Pan, 2012, 2014), the periphyton protein content was almost double that of biofloc and the reported figure for periphyton (25\% of dry matter) in substrate-added Pacific white shrimp culture (Kumar et al., 2017). It is possible that part of the residual feed was trapped in the rim of periphyton at the water-air interphase, resulting in high periphyton protein content. In tilapia ponds with substrate, the periphyton protein ranges from $14 \%$ to $17 \%$ dry matter (Azim et al., 2003). The introduction of substrate to promote periphyton growth improved Pacific white shrimp production in both conventional (Audelo-Naranjo et al., 2012; Kumar et al., 2017) and biofloc systems (Schveitzer et al., 2013). Nevertheless, the nutritional contribution of periphyton to shrimp growth in biofloc system merits further research.

\subsection{Nutrient retention efficiency}

Feed constituted more than $50 \%$ of production cost in shrimp culture (Cruz-Suárez et al., 1994). Therefore, increasing feed use efficiency is one way to make aquaculture activities profitable. This can be achieved by employing biofloc systems, where shrimp use feed more efficiently and retain more nitrogen due to the ingestion of biofloc as natural food and the enhanced enzymatic activities of the shrimp (Kumar et al., 2018; $\mathrm{Xu}$ and Pan, 2012). In aquaculture systems, ammonia nitrogen is removed through photoautotrophic uptake by algae, autotrophic bacterial conversion, and heterotrophic bacterial uptake (Ebeling et al., 2006). The addition of $\mathrm{CHO}$ facilitates the third process in which nitrogen is converted to bacterial biomass and carbon is released as carbon dioxide. In closed culture systems, the nitrogen is lost from the system as a result of denitrification which might occur following nitrification. The nitrogen retentions in shrimp and biofloc, and the total nitrogen loss in this research (Fig. 4) were comparable to previous reports for the biofloc system (Audelo-Naranjo et al., 2010; da Silva et al., 2013; Kumar et al., 2018). However, the nitrogen retentions were not different among the $\mathrm{CHO} 0$ and biofloc treatments, and among $\mathrm{CHO}$ addition frequencies. This may have stemmed from the relatively similar biofloc growth and nutritional value among treatments, and the short experimental duration. A 120-day experiment at C:N ratio of 15 showed that biofloc system had 5\% higher nitrogen retention compared to a conventional system (Kumar et al., 2018). Increased nitrogen retention due to carbohydrate addition was also reported in other shrimp species (Hari et al., 2006). Nevertheless, our research demonstrated that the nitrogen retention in shrimp was high, and the nitrogen and carbon retentions were not affected by $\mathrm{CHO}$ addition frequency.

Regardless of $\mathrm{CHO}$ addition frequencies, biofloc culture of Pacific white shrimp showed double carbon loss compared to conventional culture. This is in line with what was found for tilapia culture where the carbon fraction lost from the biofloc system doubled that from the conventional system (Hu et al., 2014). We found that Pacific white shrimp assimilated $34 \%$ of the total carbon input in conventional culture, while the reported value for Penaeus monodon was 16-21\% (Sahu et al., 2012). In biofloc culture, $846 \mathrm{~g}$ of tapioca powder per kilogram of feed fed was added to maintain a C:N ratio of 12 , more than $70 \%$ of which was not accounted for. While the economic impact of carbon loss can be reduced by using cheap by-product carbon sources (e.g. molasses), such high percentages of carbon loss may cause concerns over the environmental impacts of biofloc systems. Therefore, further research is needed to optimize the use of nutrients, specifically carbon, if the biofloc technology is to be widely disseminated.

\section{Conclusions}

The current research showed that an addition frequency of once per day is optimal and more frequent addition of $\mathrm{CHO}$ is not recommended if carbohydrate is to be applied in the culture of Pacific white shrimp.

\section{Declaration of Competing Interest}

The authors declare that they have no known competing financial interests or personal relationships that could have appeared to influence the work reported in this paper.

\section{Acknowledgements}

The authors are thankful to NWO (Dutch Research Council)-WOTRO (Science for Global Development) for their financial support for this project (Grant number: W 08.250.101), to Can Tho University in Vietnam for providing research facilities, to WorldFish for field assistance and project guidance and to Skretting (a Nutreco company) for shrimp feed and carbohydrate supply. Sincere thanks are also given to our colleagues at Animal Science Group, Wageningen University for their helpful comments during the preparation of this manuscript.

\section{References}

APHA, 1995. Standard Methods for the Examination of Water and Wastewater. Amer. Pub. Heal. Assoc. Washingt, DC.

Audelo-Naranjo, J.M., Martínez-Córdova, L.R., Voltolina, D., 2010. Nitrogen budget in intensive cultures of Litopenaeus vannamei in mesocosms, with zero water exchange and artificial substrates. Rev. Biol. Mar. Oceanogr. 45, 519-524. https://doi.org/ 10.4067/s0718-19572010000300017.

Audelo-Naranjo, J.M., Martínez-Córdova, L.R., Gómez-Jiménez, S., Voltolina, D., 2012. Intensive culture of Litopenaeus vannamei without water exchange and with an artificial substrate. Hidrobiológica 22, 1-7.

Avnimelech, Y., 2009. Biofloc technology. In: A Pract. Guid. book. World Aquac. Soc. Bat. Rouge.

Azim, M.E., Verdegem, M.C.J., Singh, M., Van Dam, A.A., Beveridge, M.C.M., 2003. The effects of periphyton substrate and fish stocking density on water quality, phytoplankton, periphyton and fish growth. Aquac. Res. 34, 685-695.

Bossier, P., Ekasari, J., 2017. Biofloc technology application in aquaculture to support sustainable development goals. Microb. Biotechnol. 10, 1012-1016. https://doi.org/ 10.1111/1751-7915.12836.

Burford, M.A., Thompson, P.J., McIntosh, R.P., Bauman, R.H., Pearson, D.C., 2004. The contribution of flocculated material to shrimp (Litopenaeus vannamei) nutrition in a high-intensity, zero-exchange system. Aquaculture 232, 525-537. https://doi.org/ 10.1016/S0044-8486(03)00541-6.

Carvalho, E.A., Nunes, A.J.P.P., 2006. Effects of feeding frequency on feed leaching loss and grow-out patterns of the white shrimp Litopenaeus vannamei fed under a diurnal feeding regime in pond enclosures. Aquaculture 252, 494-502. https://doi.org/ 10.1016/j.aquaculture.2005.07.013.

Crab, R., Defoirdt, T., Bossier, P., Verstraete, W., 2012. Biofloc technology in aquaculture: beneficial effects and future challenges. Aquaculture 356-357, 351-356. https://doi.org/10.1016/j.aquaculture.2012.04.046.

Cruz-Suárez, L.E., Ricque-Marie, D., Pinal-Mansilla, J.D., Wesche-Ebelling, P., 1994. Effect of different carbohydrate sources on the growth of Penaeus vannamei: economical impact. Aquaculture 123, 349-360. https://doi.org/10.1016/0044-8486 (94)90070-1.

da Silva, K.R., Wasielesky, W., Abreu, P.C., Wasielesky Jr., W., Abreu, P.C., 2013. Nitrogen and phosphorus dynamics in the biofloc production of the Pacific white 
shrimp, Litopenaeus vannamei. J. World Aquacult. Soc. 44, 30-41. https://doi.org/ 10.1111/jwas.12009.

de Lima, P.P., Pontes, C.S., Arruda, M.D.F., 2009. Activity pattern of the marine shrimp Litopenaeus vannamei (Boone 1931) in laboratory as a function of different feeding frequencies. Aquac. Res. 41, 53-60. https://doi.org/10.1111/j.13652109.2009.02302.x.

Ebeling, J.M., Timmons, M.B., Bisogni, J.J., 2006. Engineering analysis of the stoichiometry of photoautotrophic, autotrophic, and heterotrophic removal of ammonia-nitrogen in aquaculture systems. Aquaculture 257, 346-358. https://doi. org/10.1016/j.aquaculture.2006.03.019.

Emerenciano, M.G.C., Martínez-Córdova, L.R., Martínez-Porchas, M., Miranda-Baeza, A., 2017. Biofloc technology (BFT): a tool for water quality management in aquaculture. Water Qual. 5, 92-109.

FAO, 2020. The State of World Fisheries and Aquaculture 2020. FAO. https://doi.org/ $10.4060 /$ ca9229en.

Gamboa-delgado, J., Molina-poveda, C., Cahu, C., 2003. Digestive enzyme activity and food ingesta in juvenile shrimp Litopenaeus vannamei (Boone, 1931) as a function of body weight. Aquac. Res. 34, 1403-1411. https://doi.org/10.1111/j.13652109.2003.00959.x.

Gao, L., Shan, H.-W., Zhang, T.-W., Bao, W.-Y., Ma, S., 2012. Effects of carbohydrate addition on Litopenaeus vannamei intensive culture in a zero-water exchange system. Aquaculture 342-343, 89-96. https://doi.org/10.1016/j.aquaculture.2012.02.022.

Hargreaves, J.A., 2006. Photosynthetic suspended-growth systems in aquaculture. Aquac. Eng. 34, 344-363. https://doi.org/10.1016/j.aquaeng.2005.08.009.

Hari, B., Madhusoodana Kurup, B., Varghese, J.T., Schrama, J.W., Verdegem, M.C.J., 2006. The effect of carbohydrate addition on water quality and the nitrogen budget in extensive shrimp culture systems. Aquaculture 252, 248-263. https://doi.org/ 10.1016/j.aquaculture.2005.06.044.

Hu, Z., Lee, J.W., Chandran, K., Kim, S., Sharma, K., Khanal, S.K., 2014. Influence of carbohydrate addition on nitrogen transformations and greenhouse gas emissions of intensive aquaculture system. Sci. Total Environ. 470-471, 193-200. https://doi. org/10.1016/j.scitotenv.2013.09.050.

ISO 5983, 2005. Animal Feeding Stuff - Determination of Nitrogen Content and Calculation of Crude Protein Content - Kjeldhal Method. Geneve, Switzerland, Int Organ. Stand.

ISO 5984, 2002. Animal Feeding Stuff - Determination of Crude Ash. Geneve, Switzerland, Int. Organ. Stand.

ISO 6492, 1999. Animal Feeding Stuff - Determination of Fat Content. Geneve, Switzerland, Int. Organ. Stand.

Janeo, R.L., Corre, V.L., Sakata, T., 2009. Water quality and phytoplankton stability in response to application frequency of bioaugmentation agent in shrimp ponds. Aquac. Eng. https://doi.org/10.1016/j.aquaeng.2009.01.001.

Junning, C., Zhou, X., Xue, Y., Lucentea, D., Laganaa, C., 2019. Top 10 species groups in global aquaculture 2017. In: Food Agric. Organ. United Nations.

Khanjani, M.H., Sajjadi, M.M., Alizadeh, M., Sourinejad, I., 2016. Nursery performance of Pacific white shrimp (Litopenaeus vannamei Boone, 1931) cultivated in a biofloc system: the effect of adding different carbon sources. Aquac. Res. https://doi.org/ 10.1111/are.12985 n/a-n/a.

Kumar, V.S., Pandey, P.K., Anand, T., Bhuvaneswari, R., Kumar, S., Santhana, K.V., Pandey, P.K., Anand, T., Bhuvaneswari, R., Kumar, S., 2017. Effect of periphyton (aquamat) on water quality, nitrogen budget, microbial ecology, and growth parameters of Litopenaeus vannamei in a semi-intensive culture system. Aquaculture 479, 240-249. https://doi.org/10.1016/J.Aquaculture.2017.05.048.

Kumar, V.S., Pandey, P.K., Anand, T., Bhuvaneswari, G.R., Dhinakaran, A., Kumar, S., 2018. Biofloc improves water, effluent quality and growth parameters of Penaeus vannamei in an intensive culture system. J. Environ. Manag. 215, 206-215. https:// doi.org/10.1016/J.JENVMAN.2018.03.015.

Liu, G., Zhu, S., Liu, D., Guo, X., Ye, Z., 2017. Effects of stocking density of the white shrimp Litopenaeus vannamei (Boone) on immunities, antioxidant status, and resistance against Vibrio harveyi in a biofloc system. Fish Shellfish Immunol. 67, 19-26. https://doi.org/10.1016/J.FSI.2017.05.038.
Panigrahi, A., Sundaram, M., Chakrapani, S., Rajasekar, S., Syama Dayal, J., Chavali, G., 2019. Effect of carbon and nitrogen ratio $(\mathrm{C}: \mathrm{N})$ manipulation on the production performance and immunity of Pacific white shrimp Litopenaeus vannamei (Boone, 1931) in a biofloc-based rearing system. Aquac. Res. 50, 29-41. https://doi.org/ 10.1111/are.13857.

Peixoto, S., Silva, E., Costa, C.B., Nery, R.C., Rodrigues, F., Silva, J.F., Bezerra, R., Soares, R., 2018. Effect of feeding frequency on growth and enzymatic activity of Litopenaeus vannamei during nursery phase in biofloc system. Aquac. Nutr. 24, 579-585. https://doi.org/10.1111/anu.12591.

Pontes, C.S., De Lima, P.P., de Arruda, M.F., 2008. Feeding responses of juvenile shrimp Litopenaeus vannamei (Boone) fed at different frequencies under laboratory conditions. Aquac. Res. 39, 1416-1422. https://doi.org/10.1111/j.13652109.2008.02011.x.

Rajkumar, M., Pandey, P.K., Aravind, R., Vennila, A., Bharti, V., Purushothaman, C.S., 2016. Effect of Different Biofloc System on Water Quality, Biofloc Composition and Growth Performance in Litopenaeus vannamei (Boone, 1931). https://doi.org/ 10.1111/are.12792.

Reis, J., Novriadi, R., Swanepoel, A., Jingping, G., Rhodes, M., Davis, D.A., 2020. Optimizing feed automation: improving timer-feeders and on demand systems in semi-intensive pond culture of shrimp Litopenaeus vannamei. Aquaculture 519, 734759. https://doi.org/10.1016/j.aquaculture.2019.734759.

Robertson, L., Wrence, A.L.L., Castille, F.L., 1993. Effect of feeding frequency and feeding time on growth of Penaeus vannamei (Boone). Aquac. Res. 24, 1-6. https://doi.org/ 10.1111/j.1365-2109.1993.tb00823.x.

Sahu, B.C., Adhikari, S., Dey, L., 2012. Carbon, nitrogen and phosphorus budget in shrimp (Penaeus monodon) culture ponds in eastern India. Aquac. Int. 21, 453-466. https://doi.org/10.1007/s10499-012-9573-x.

Schveitzer, R., Arantes, R., Baloi, M.F., Costódio, P.F.S., Arana, L.V., Seiffert, W.Q., Andreatta, E.R., 2013. Use of artificial substrates in the culture of Litopenaeus vannamei (biofloc system) at different stocking densities: effects on microbial activity, water quality and production rates. Aquac. Eng. 54, 93-103. https://doi. org/10.1016/J.AQUAENG.2012.12.003.

Sookying, D., Silva, F.S.D., Davis, D.A., Hanson, T.R., 2011. Effects of stocking density on the performance of Pacific white shrimp Litopenaeus vannamei cultured under pond and outdoor tank conditions using a high soybean meal diet. Aquaculture 319, 232-239. https://doi.org/10.1016/J.AQUACULTURE.2011.06.014.

Velasco, M., Lawrence, A.L., Castille, F.L., 1999. Effect of variations in daily feeding frequency and ration size on growth of shrimp, Litopenaeus vannamei (Boone), in zero-water exchange culture tanks. Aquaculture 179, 141-148. https://doi.org/ 10.1016/S0044-8486(99)00158-1.

Wasielesky Jr., W., Bezerra, A., Poersch, L., Hoffling, F.B., Krummenauer, D., 2020. Effect of feeding frequency on the white shrimp Litopenaeus vannamei during the pilot-scale nursery phase of a superintensive culture in a biofloc system. J. World Aquacult. Soc. 51, 1175-1191. https://doi.org/10.1111/jwas.12694.

Wasielesky, W., Atwood, H., Stokes, A., Browdy, C.L., 2006. Effect of natural production in a zero exchange suspended microbial floc based super-intensive culture system for white shrimp Litopenaeus vannamei. Aquaculture 258, 396-403. https://doi.org/ 10.1016/J.AQUACULTURE.2006.04.030.

Xu, W.-J., Pan, L.-Q., 2012. Effects of bioflocs on growth performance, digestive enzyme activity and body composition of juvenile Litopenaeus vannamei in zero-water exchange tanks manipulating $\mathrm{C} / \mathrm{N}$ ratio in feed. Aquaculture 356-357, 147-152. https://doi.org/10.1016/j.aquaculture.2012.05.022.

Xu, W.J., Pan, L.Q., 2014. Dietary protein level and C/N ratio manipulation in zeroexchange culture of Litopenaeus vannamei: evaluation of inorganic nitrogen control, biofloc composition and shrimp performance. Aquac. Res. 45, 1842-1851. https:// doi.org/10.1111/are.12126.

Xu, W.J., Morris, T.C., Samocha, T.M., 2016. Effects of C/N ratio on biofloc development, water quality, and performance of Litopenaeus vannamei juveniles in a biofloc-based, high-density, zero-exchange, outdoor tank system. Aquaculture 453, 169-175. https://doi.org/10.1016/j.aquaculture.2015.11.021. 